\title{
Rursus
}

Russus

Poiétique, réception et réécriture des textes antiques

$4 \mid 2009$

Erotica

\section{Les figures masculines dans l'Enéide de Virgile}

Résumé de mémoire de littérature latine sous la direction de Monsieur Evrard Delbey (2007-2008)

The Male Figures in Virgil's Aeneid

Laura Biancamaria

\section{OpenEdition}

Édition électronique

URL : http://journals.openedition.org/rursus/253

DOI : $10.4000 /$ rursus. 253

ISSN : 1951-669X

Éditeur

Université Nice-Sophia Antipolis

Référence électronique

Laura Biancamaria, «Les figures masculines dans l'Enéide de Virgile », Rursus [En ligne], 4 | 2009, mis en ligne le 26 janvier 2009, consulté le 03 mai 2019. URL : http://journals.openedition.org/rursus/253 DOI : 10.4000/rursus.253

Ce document a été généré automatiquement le 3 mai 2019.

Rursus 


\section{Les figures masculines dans l'Enéide de Virgile}

Résumé de mémoire de littérature latine sous la direction de Monsieur

Evrard Delbey (2007-2008)

The Male Figures in Virgil's Aeneid

Laura Biancamaria

\section{Version française}

1 Le mémoire analyse la conception du modèle du uir romain dans l'épopée virgilienne. L'univers du uir est étudié à travers les diverses figures masculines. Comment, à partir d'un personnage mythologique, s'élabore la conception du modèle du uir romain à l'époque de Virgile? car il s'agit de peindre, dans ce poème épique, l'histoire de l'homme et de ses multiples manières de se voir et de se penser. Comment se crée une identité romaine à travers un poème unissant légende et histoire? et comment cette même identité du bon uir se dégage-t-elle de la multitude des personnages présents sur la scène?

2 Plus qu'une simple épopée, l'Enéide est une peinture de la légende romaine, vouée à mettre en place des valeurs. Le point de rencontre entre l'histoire légendaire des Romains, d'une part, et de la littérature, d'autre part, constitue une source riche d'informations sur la conception que les Latins se faisaient du bon uir. Rappelons d'ailleurs que le terme uir est traduit de deux manières dans l'Enéide, soit par "guerrier ", soit par "homme"; le terme de uir est étymologiquement lié à celui de uirtus et donc rattaché à l'ardeur guerrière.

On remarque que Virgile laisse apparaître une certaine affection pour ses personnages, avec, toujours à l'esprit, le souci du modèle et de l'exemplarité; en effet, même s'ils peuvent par moment apparaitre cruels et détestables, ils sont avant tout humains avec leurs faiblesses et leurs qualités.. En réalité, Virgile ne critique pas les faiblesses de l'âme humaine, il critique le fait que ces faiblesses peuvent l'emporter sur les uirtutes. Pour la 
clarté de l'exposé, l'étude de l'identification du uir comporte deux volets : celle qui tient à son aspect extérieur, et celle qui s'attache plus précisément à l'étude de la morale. La beauté n'est pas un trait déterminant dans l'épopée virgilienne pour caractériser le héros; ce sont en effet les valeurs morales qui permettent de parvenir à l'identification du uir. Le héros troyen s'éloigne ainsi du risque d'une idéalisation, et l'auteur laisse par cette occasion comprendre que la beauté du corps est une valeur insuffisante. Le héros virgilien est loin d'atteindre la perfection, car il reste plus proche de l'humain que du divin, et manifeste des carences, des insuffisances. Les personnages secondaires manifestent également des inaptitudes et des contradictions. Mais à aucun moment Virgile ne brosse le portrait d'homme entièrement mauvais ou bon; pour chaque personnage il prend soin de composer un caractère particulier et nuancé. Ainsi, les circonstances révèlent une identité changeante des personnages, et c'est donc leur identité mobile que peint Virgile. La noirceur de l'âme humaine est l'un des aspects intéressants de l'Enéide, et elle se manifeste dans les deux camps. En réalité, il ne s'agit pas d'une vision manichéenne qui opposerait systématiquement le bien et le mal, les bons et les mauvais. L'épopée virgilienne se présente davantage comme une mosaïque de sentiments et d'aspects variés de l'âme humaine dans chaque personnage. L'auteur le montre dans cette étude, l'œuvre d'Enée est de servir la nouvelle Troie, et l'exemplum du uir repose sur cet apprentissage du pouvoir, cette compréhension de la volonté divine et le choix du héros troyen de suivre les décisions de Jupiter. Bien que l'épopée soit un chant de guerre, l'Enéide n'en n'est pas moins un portrait philosophique de l'homme, et elle souligne l'un de ses grands pouvoirs : sa possibilité de choisir et d'être responsable de son sort. Elle est bien évidemment liée à la fondation de Rome puisqu'il s'agit là du rôle d'Enée, mais elle est surtout la construction d'un modèle de l'homme romain, grâce à une morale exaltant exprimée par le uir. La notion de modèle n'est cependant jamais clairement explicitée dans l'Enéide, et ce ne sont pas les qualités d'Enée qui font de lui un modèle : ce sont au contraire son apprentissage et la maturation qu'il acquiert durant sa mission qui vont faire de lui un exemplum. C'est en réalité dans la première moitié de l'Enéide, que l'on a affaire à un personnage en construction. Un homme est ce qu'il fait, c'est-à-dire qu'il se définit dans le cas d'Enée par les exploits accomplis reflétant sa valeur. Un homme est donc ce qu'il vaut. En ce qui concerne la conception du pouvoir politique, l'épopée reste très négative, les figures royales étant à proprement parler inaptes à représenter un modèle satisfaisant, à l'exception naturellement d'Enée. Le roi, modèle hérité des Grecs, est une figure que l'épopée propose de dépasser. Enée est le seul à percevoir que ce statut de roi n'est plus satisfaisant, ne permettant guère un bon gouvernement du peuple. L'affaiblissement des autres peuples de l'Enéide tient toujours à l'inaptitude du roi. Cependant Virgile laisse clairement transparaître l'idée selon laquelle la société ne peut vivre que grâce à la clef de voûte que représente son chef, et le héros troyen figure l'assurance de la cohésion de la communauté.

4 Ainsi Virgile a pour originalité et pour difficulté de transporter en quelque sorte ce modèle républicain à l'époque impériale, au moment où Rome change de régime politique et passe de la République à l'Empire. Il a donc besoin d'une espèce d'héroïsation lui permettant, grâce à Enée, d'inscrire Rome dans une continuité. Quels que soient les régimes politiques il y a une permanence de l'homme romain idéal. Evidemment l'intervention des dieux est importante puisqu'elle permet d'éterniser ce modèle masculin du uir. Et cela seul le poète peut se le permettre, car un historien aura du mal à rester crédible s'il recourt aux dieux pour justifier la permanence d'un modèle moral. Virgile oublie volontairement l'enseignement épicurien qui considère que les dieux 
existent dans leur propre monde et ne se préoccupent jamais des affaires humaines. Dans l'épopée, au contraire, préside un dieu actif en la personne de Jupiter, intervenant dans le monde des hommes. Virgile se met ainsi au service de Rome et de son Histoire.

\section{Version anglaise}

5 This dissertation analyses the notion of the uir in the Virgilian epic poem the Aeneid through diverse male figures and asks how this concept elaborates from a mythological character in Virgil's times. This epic poem is about the depiction of the history of man as well as his various ways of seeing himself and thinking about himself. How is Roman identity created through a poem? How does this very same identity of the good uir emanate from the multitude of characters present on stage?

than a simple epic, the Aeneid is a depiction of the Roman legend, and its purpose is to put values in place. The meeting point between the Romans' legendary history on the one hand, and literature on the other hand, constitutes a rich pool of information about the notion that the Romans have good uir. It must be remembered that uir is translated in the Aeneid, once as "warrior", and once as "man". It is etymologically related to uirtus, and therefore linked to warlike ardour.

7 It is interesting to note that Virgil displays affection for his characters. Indeed they can appear cruel and detestable, but they are first and foremost human with all their weaknesses and qualities. Again there is the concern to be an example, a model. Virgil does not criticise the weakness of the human soul but the fact that they can win over the uirtutes. With concern for clarity, the study of the identification of the uir was separated in two sections: the external aspect, and the moral aspect. Beauty is not a determinant in characterising the hero in Virgil's epic. It is first and foremost moral values that will enable the reader to identify the uir. The Trojan hero sets himself far from the risk of idealisation, and the author makes one aware that external beauty is insufficient a value. The Virgilian hero is far from attaining perfection and is much closer to the human than the divine. He shows inadequacies and insufficiencies. The other characters show ineptitudes and contradictions as well. As shown, Virgil never portrays man as entirely good or entirely evil, but takes care to show that each character is balanced. Therefore circumstances will reveal a changing identity of the characters.

The darkness of the human soul is one of the interesting points in the Aeneid, and it is present in both camps. It is absolutely not a Manichean vision which would oppose Good and Evil. The epic is more of a mosaic of feelings as well as various aspects of the human soul in each character. Aeneas' task is to serve the new Troy, and the exemplum of the uir rests on this learning of power, this understanding of the divine will, and the choice made by the Trojan hero to follow Jupiter's decisions. Although the epic is a war cry the Aeneid is no less than a philosophical analysis of man and shows one of his great powers, namely his being able to chose and decide his fate. It is obviously linked to the founding of Rome, which is Aeneas' role, but it is also the elaboration of the model of the Roman man due to a morale exalting the uir. The notion of model is never explicit in the Aeneid. Aeneas' qualities do not make him a model, but it is his learning and his coming to maturity during his mission that will enable him to become an exemplum. The first part of the 
Aeneid is about a growing character. A man is defined by what he does, and Aeneas defines himself by achievements that reflect his valour. The concept of political power is very negative, the royal figures are bad examples, with the exception of Aeneas who is the only one shown in a positive light. The epic is going beyond the inherited image of the Greek king. Aeneas is the only one aware that the status of king is no longer satisfying and does not enable good rule over the people. However Virgil clearly shows the idea that society can only survive due to the keystone that is at its head. The Trojan hero is the assurance that community cohesion exists. The weakness of other people in the Aeneid is due to the king's inadequacy.

9 Virgil's originality as well as difficulty is to adapt this republican model to the imperial time when Rome is going from republic to empire. He therefore needs a hero like Aeneas to ensure the continuity of Rome. Whatever political regime may be in place, the model of the ideal Roman man remains. There is no doubt that the intervention of the gods is important because it enables the perpetuation of this male model of the uir. Only the poet can do this. A historian would not be credible if he relied on the gods to justify the permanence of a moral example. This is the poet's strength. Virgil voluntarily forgets the Epicurean teaching which considers that the gods exist in their own world and do not interfere in human matters. Here we have Jupiter as an active god interfering with the human world. Virgil puts himself to the service of Rome and its history.

\section{AUTEUR}

\section{LAURA BIANCAMARIA}

Etudiante de Mastère (Lettres classiques) 